\title{
REFORMATION OF CUSTOMS SERVICE OF UKRAINE TO ACHIEVE THE GOALS OF SUSTAINABLE DEVELOPMENT
}

\author{
Yevhen Borshchuk', Yurii Dumiak²
}

\begin{abstract}
The objective of the article is a systemic analysis of the approaches to reformation of the customs sphere, determination of the role of customs service in the process of ensuring a sustainable development under the present-day conditions. Eurointegration strategy of Ukraine necessitates the need for reformation of the national customs system in order to conform to the standards of the World Customs Organization and the perspective adaptation to the European requirements, elaboration of the development strategy with the purpose of integration with the developed countries of the world, harmonization of economic trade and ecological processes. Methodology. In the course of this analysis the customs service was considered as a complex open system with application in the research of the methodology of systemic analysis, which allowed to put emphasis on separate aspects of the specific character of its functioning. Results. In any country, customs service is an integral part of the system of state administration of the foreign economic activity, one of the important state institutes of social and economic processes administration. It ensures the balance of interests of all participants of international trade enshrined in the current conventions and agreements on the level of the international law. Modernization of the national customs system under the conditions of the European integration processes has to become an important mechanism of social and economic development and international collaboration of Ukraine. Under the present-day conditions customs service plays an important role in the achievement of goals established by the UN in the sphere of sustainable development till 2030. Some of these goals are directly connected with the strategic mission of the customs service and that is why it is important to ensure appropriate conditions for functioning of the customs service for the successful accomplishment of the tasks of sustainable development in the social, economic and ecological spheres. The key priorities of activities of the national customs system must ensure accomplishment of the main tasks of the customs authorities in the context of achieving the goals of sustainable development formulated by the World Customs Organization: formation of the favorable, safe, just and sustainable business environment for economic growth, ensuring social justice, facilitation of improving stability of the global, national and regional ecological systems and combating the climate changes. Practical implications. The performed analysis of particularities of the customs system functioning and its objectives allows to determine the role of the customs service in the achievement of the Goals of sustainable development till 2030, to highlight the key priorities in resolving the environmental problems, to form the potential of sustainable development. For Ukraine these are modernization of national society and minimization of consequences of existence of the corruption schemes. Value/originality. The use of the systemic analysis allows to detect the main problems in functioning of the customs service taking into consideration the specific character of its functioning under the present-day conditions.
\end{abstract}

Key words: customs service, sustainable development, goals of sustainable development, system analysis, World Customs Organization.

Jel Classification: E42, Q01

\footnotetext{
Corresponding author:

${ }^{1}$ Lviv Regional Institute of State Administration

of the National Academy of State Administration

under the President of Ukraine, Ukraine.

${ }^{2}$ Lviv Regional Institute of State Administration

of the National Academy of State Administration

under the President of Ukraine, Ukraine.

E-mail: 88dym88@gmail.com

ORCID: http://orcid.org/0000-0003-1901-9177
} 


\section{Introduction}

Social and economic transformations taking place in the Ukrainian society in the beginning of the $21^{\text {st }}$ century are accompanied by complicated and controversial processes: transformation of policy making organs, reformation of economic foundations of functioning of the national economic system, profound changes in the role of the state institutions in regulation of social relations, growing social inequality. All this is taking place against the background of the global processes of economic integration of the states, which predetermines the need for the formation of effective tools for regulation of the social and economic development and optimization of functioning of the state regulation in various spheres, particularly, in the customs sphere. As the researchers point out, substantial rise in the scale of turnover of commodities between Ukraine and other countries against the background of economic slowdown under the conditions of pandemics fuels up withdrawal into the shadows in the sphere of customs-legal regulation of foreign economic relations, which causes tremendous nonreceipt of payments to the budget.

Eurointegration strategy of Ukraine necessitates improvement of the customs system in accordance with the standards of the World Customs Organization and the perspective adaptation to the European requirements. Modern challenges for Ukraine explained by the growing scale of globalization necessitate elaboration of the strategy of social and economic development aiming at integration with the developed and economically successful nations of the world and harmonization of the diverse processes in foreign sphere - economy, trade, legal arrangements, etc. Integration of Ukraine into the global economic system necessitates selection of the effective foreign economic policy that in many respects depends on the structure and character of functioning of the customs sphere (Melnyk, Todoshchuk, Adamiv, 2018).

The problems of functioning of the customs system and principles of formation and implementation of the customs policy and customs activities draw more and more attention of scientists and experts, analysis of the various aspects of development of the customs affairs is an inexhaustible subject of research for the leading scientists. The majority of the Ukrainian researchers are of the opinion that the pressing problem of modernization of the national customs service is absence of a quality state strategy of the customs service development that would clearly identify the top-priority goals of its functioning in the long-term perspective and then transform into specific tactical measures for implementation of such strategy (Martynyuk, 2010). The internal and external constraining factors of development of the state customs service are also insufficiently studied. In general, scientific research of these problems is rather multifaceted but the direction of strategic development of the customs sphere in the context of transition of the national economy to the principles of sustainable development has not been studied sufficiently. The objective of this article is to conduct analysis of modern trends in the improvement of administration of the customs component in Ukraine, to assess the impact of the customs service on sustainable development taking into consideration the determinant of the global environment.

\section{Sustainable development concept}

Strategic tasks of civilizational development have been formulated in the sustainable development concept approved at the United Nations Conference on Environment and Development (Rio de Janeiro, 1992) the main trends of which were outlined by the Millennium Goals and the Sustainable Development Goals for the period after 2015. The $\mathrm{UN}$, proceeding from the analysis of execution of the tasks to achieve the Millennium Goals by its Resolution 70/1 dated September 25, 2015 adopted by the UN General Assembly "Transforming our world: the 2030 Agenda for Sustainable Development" approved the agenda in the sphere of sustainable development in the period after 2015.

The feature of the Sustainable Development Goals till 2030 is a considerable attention to the growth of creative and innovation potential of international business in the context of meeting challenges of sustainable development. The World Customs Organization has formulated the main tasks of the customs authorities in the context of achievement of sustainable development aiming at the formation of favorable, safe, just and sustainable business environment for economic development. This will permit enterprises, especially micro-, small and medium enterprises, to expand their spheres of activities and create prerequisites for a more active participation in the global trade. That is why the pressing problem becomes the problem of identifying the meaning, place and role of the customs control, improvement of functioning of the customs system in the formation of financial 
resources of sustainable development (World Customs Organization, 2018).

\section{Customs as the state administration institute}

Throughout the entire period of the formation of modern civilization, the customs has been and remains one of the most essential factors of statehood and independence of any country, its financial sovereignty. The customs system is a component of the primary principal features of an independent country that necessitates the construction of the effective national customs system. It has always been one of the key factors of functioning of the state ensuring its national security and economic interests of the country. To assess activity of the customs, first of all, it is necessary to determine its place in the system of the state institutes that control social and economic processes. As a part of the economic system of the country the customs, aside from the performance of its traditional functions of administration in the sphere of taxation and regulation of foreign trade, also acts as a social and economic institute where the customs service is demonstrated in the form of a special state service. The peculiarity of provision and consumption of the customs services is their rigid legislative regulation - the list of the rendered customs services is limited by the tasks and functions of the customs authorities, while the number and quality of the services is regulated by the law (Berezhnyuk, 2002; Lypovska, 2005). Customs administration must observe the balance of interests of all participants of foreign trade in its activity (first of all, social and economic, legal and other interests of its country, society), enshrined in the current conventions and agreements - on the level of the international law taking into account the national interests by way of (Pashko, 2004):

- creation of the conditions (legislative, norma-tive legal, technological, communication, infrastructural) that do not prevent lawful trade and crossing customs borders by transport, cargoes, passengers;

- reconcilement of the national and international trade and customs legislation and the tax policy regulating foreign economic activity;

- collaboration with the world community, relevant bodies inside the country in the joint struggle with arms trafficking, smuggling of drugs and other prohibited, dangerous for human health goods and cargoes, that inflict environmental harm as well as with commercial fraud;
- recognition of justifiability and eligibility of the measures taken to protect the internal market and domestic commodity producers from foreign economic expansion by the world trade community and individual foreign trade partners, and from the policy of discrimination of commodities manufactured by the national producer.

The main tasks of the customs service include (State Customs Service, 2019):

- correct application, steadfast observance and inadmissibility of non- implementation of the requirements of the laws of Ukraine pertaining to the state customs service;

- performance of obligations envisaged by the international agreements of Ukraine on the state customs service in accordance with the requirements of laws;

- ensuring customs control and execution of customs formalities pertaining to the goods, commercial transport vehicles crossing the customs border including those that do it on the basis of electronic documents (online customs filing) with the aid of technical control means, etc.;

- collection of customs payments, control of correct calculation, timeliness and completeness of their payment, taking measures for their recovery by enforcement if needed, organization of applying guarantees to ensure collection of customs payments; - control of the observance of rules for transfer of currency valuables;

- protection of the intellectual property rights, taking measures to prevent transfer of commodities across the border if this is done with violation of the intellectual property rights;

- prevention and struggle with smuggling, combating violation of the customs rules on the entire customs territory of Ukraine;

- control of the activity of enterprises rendering services for declaration of goods, movement and warehousing of goods transferred across the border or that are under customs supervision, and carrying on operations with such goods; issuance of permits to carry on the mentioned types of activities; issuance of the certificates of the authorized economic operator; - verification (authentication of reliability) of the certificates of origin of the goods from Ukraine and issuance of the certificates of origin in the established cases;

- application of measures envisaged by the law for the customs tariff and non-tariff regulation of foreign economic activity and exercising other powers established by the laws of Ukraine. 
The environment, in which the customs system of Ukraine functions, is determined by two important factors: the European integration processes and the processes of transition to the principles of sustainable development. The important task of social and economic development of Ukraine in the context of the European integration processes is reorientation of the national economy towards the foreign economic segment taking into account not only the European standards, but also the national interests of Ukraine and introduction of modern methods and levers of state regulation of foreign economic activity. Modernization of the national customs system under the conditions of the European integration processes becomes an important mechanism for social and economic development and international collaboration of Ukraine for the upgrading economic level of social development creating new opportunities for carrying on business and for interhuman contacts, improvement of environmental situation, expanding the limits of independence of local power bodies and strengthening local democracy.

The World Customs Organization recognized promotion of ensuring a sustainable future, solution of the tasks in social, economic and ecological spheres and in the sphere of health care as the main trends of its activity for the achievement of the sustainable development goals till 2030. To this end it is important that customs, successfully resolving the assigned tasks, would continuously increase its efforts for the effective and more active actions (World Customs Organization, 2020).

\section{Customs system \\ and Sustainable Development Goals}

In contrast to the Goals of Development, the features of Sustainable Development Goals till 2030 are the growing attention to the problems of formation of innovation potential of international business in the context of meeting the challenges of sustainable development. As noted in the UN documents, the Goals of Sustainable Development outline the global priorities of sustainable development and aspirations for the period till 2030. They aim at mobilizing efforts of the world community on a number of common goals and tasks. The SDG calls on the governments, business and general public of all countries to act together on the world scale to overcome poverty and create decent conditions for life and opportunities for all on the planetary scale. The goals of sustainable development is a universal plan of actions for the flourishing of all peoples and countries of the planet that requires participation of all interested parties on the basis of partnership relations (Compass Guide Ukrainian, 2016).

The Goals of Sustainable Development can be achieved and provided only when transition is made to the principles of global partnership and collaboration in support of business. As Ban Ki-moon, Secretary-General of the United Nations, has noted in his time, "business is a vitally important partner for the achievement of the Sustainable Development Goals. Companies can get involved in it through their principal types of activity, and we apply to the companies of the entire world with request to assess their influence, set the ambitious goals and report on the results openly and transparently" (World Customs Organization, 2020). The national customs authorities in their activities must ensure:

- promotion of innovations, protection of intellectual property rights, prevention of penetration of poor quality, counterfeit and other goods that do not meet requirements of relevant standards into the national markets, enhancement of combating international organized crime and terrorism, elaboration of measures against money laundering, human, drugs and weapons trafficking and other serious crimes.

- domination of social justice and openness through lowering trade barriers, harmonization of customs activities regarding reduction of the time and financial costs of transporting goods across borders, boosting of trade, increase in earnings and employment, promotion of national and international investments.

- promotion of stability of the global, national and regional social and economic systems and struggle with the climate change by way of efficient performance of multilateral agreements aiming at combating illegal trade in hazardous waste and ozone-destroying substances, combating trade in endangered species and prevention of the spreading of alien species, plant and animal diseases, collection of carbon dioxide taxes.

In the foreword to "Green Customs Guide to Multilateral Environmental Agreements" executive director of the UNEnvironmentalProgrammeAchim Steiner and former secretary general of the World Customs Organization Michel Danet note: "Today customs officers are aware that their traditional role as guardians of the trading system is evolving into a more nuanced one encompassing different 
dimensions of sustainable development related to the well-being and protection of society. Now we are asking customs officers to be at the frontline not only for trade, but also for environmental protection purposes, and to contribute to the greening trade." (UN Environmental Programme, 2008).

From the standpoint of transition to the principles of sustainable development, it is necessary to single out two important trends in activity of the customs. Environmental: ensuring execution of generally adopted international agreements: The Basel Convention on the Control of Transboundary Movements of Hazardous Wastes and their Disposal, The Cartagena Protocol on Biosafety, The Convention on the Prohibition of the Development, Production, Stockpiling and Use of Chemical Weapons and on their Destruction, The Convention on International Trade in Endangered Species of Wild Fauna and Flora, The Montreal Protocol on Substances that Deplete the Ozone Layer, The Rotterdam Convention on the Prior Informed Consent Procedure for Certain Hazardous Chemicals and Pesticides in International Trade and The Stockholm Convention on Persistent Organic Pollutants. For Ukraine, the role of the customs in this context is very important in resolving the problem of destructive logging. According to various data, forests in Ukraine occupy the area of approximately $16-17 \%$ of total territory (about 10.6 million hectares), which is considerably less than the average index in Europe (35.4\%). It is natural that the state policy must aim at the increase of forested territory. At the same time, illegal logging and sale of timber, plundering and smuggling of timber became a serious problem for Ukraine. According to the World Wildlife Fund, Ukraine is the world major supplier of charcoal exporting it to the European Union countries. In 2018, import of charcoal from Ukraine attained $22 \%$ of total volume of logging. To this end, according to Johannes Zahnen, Senior Forest Policy Officer of WWF Germany, starting from the date of prohibition of export of round wood from Ukraine the state has almost doubled export of charcoal in two years. According to the survey of the British non-governmental organization Earthsight studying the problems of illegal logging in the world, in 2018 Ukraine became the major exporter of illegal wood to the European Union. Ukrainian commercial timber under the guise of firewood is sold to the European wood processors who produce furniture, flooring, panels and other products out of it. It is profitable for the European entrepreneurs - they save their forests, buy cheap Ukrainian timber, process it and receive added value, jobs and taxes (Ukrainian Universal Exchange, 2020; State Forest Agency, 2020). Without any special calculations it is fair to say that modernization of customs service, elimination of the corruption element in the customs processes will essentially diffuse the problem of logging in the Ukrainian forests.

Financial sphere of activities of the customs, under which we understand formation of the financial potential of sustainable development, is important for the achievement of the goals of sustainable development on the basis of the considerable financial flows that pass through the customs by way of legalization of their movement. Generally speaking, financial potential is one of the key elements of sustainable development. In the most general case, financial potential of sustainable development is interpreted as a totality of financial opportunities for the development in the interests of socio-ecological and economic progress (Herasymchuk, Vakhovych, Kaminska, 2006).

Financial opportunities for the growth of receipts to the budget from the customs are tremendous. In 2018, the volume of smuggled commodities attained 11.9 billion USD, which is nearly one fifth of total volume of imports to Ukraine in 2018. According to some calculations, only under the scheme of "suit jackets" (shuttle passage of the residents of near-border regions), Ukraine loses about 700 million EUR per year. Direct losses of the budget from smuggling through the short-received mandatory payments are estimated at 3.2 billion USD, losses in the domestic market are twice the size of that (Kravchenko, 2019).

Like in the case of the environmental trend in its activity, the main task of the customs towards the increase of its contribution to the formation of the financial potential of sustainable development is putting things in functioning of the customs system in good order. The customs must not be an instrument for serving interests of certain oligarchic clans, butan effective mechanism ensuringaccomplishment of social and economic development of the state.

\section{Conclusions}

Thus, following the analysis of the goals and the specific nature of functioning of the customs system it will be fair to say that customs is capable of making a sizable contribution to the achievement of goals of sustainable development both on the global and on the national levels. Under the present-day condition 
the traditional role of the customs in supporting foreign economic activity is supplemented with the role of an essential factor in resolving environmental problems that have no borders, and its growing role in the processes of formation of the financial potential of sustainable development.

The establishment and development of the customs system of Ukraine is taking place under the conditions of complicated transformation processes that involve all spheres of vital activities of the state. The customs service serves to a certain extent as an important mechanism of social and economic development and international collaboration of Ukraine, it creates certain opportunities for the conduct of business. At the same time the customs sphere almost more than all other state institutions encounters the effects of the corruption schemes that in no small degree distort functioning of the customs system.

It is common knowledge that Ukraine possesses a great amount of various natural and human resources on which foundation it is possible to form a tremendous potential of sustainable development. To resolve the problem of potential sustainable development formation, for Ukraine the need to create the appropriate institutional conditions becomes prior. Very often the functioning state institutions by their activities protect interests of separate industrial-oligarchic groups but not the public interests, which can be seen from the work of the customs authorities of Ukraine.

Transition of the national economic system of Ukraine to the principles of sustainable development necessitates a radical upgrading of the national social and economic system within the framework of general civilizational processes of social development. The basis of such upgrading must become consolidation of the role of the civil society in the processes of sustainable development, ensuring transparency in activities of the state institutions, elaborating strategy and goals of sustainable development till 2030.

\section{References:}

Melnyk, O. H., Todoshchuk, A. V., \& Adamiv, M. Ye. (2018). Experience of France in the construction and functioning of the customs system: projection on Ukraine under the conditions of eurointegration. Business Inform, no. 7, pp. 38-43. (in Ukrainian)

Martynyuk, V. P. (2010). Customs system and economic security of the state: theory and methodology. Ternopil: Aston. (in Ukrainian)

Berezhnyuk, I. H. (2002). Structure of institutional mechanisms in the system of customs affairs administration. Herald of the Academy of Customs Service of Ukraine, no. 3, pp. 65-69. (in Ukrainian)

Lypovska, N. A. (2005). Customs service in the system of public service Ukraine. Current problems of state administration: collection of scientific works. Ed. 1 (19), pp. 208-217. (in Ukrainian)

Pashko, P. V. (2004). Fundamentals of Customs Service in Ukraine. Kyiv: Znannya Publishers. (in Ukrainian)

World Customs Organization (2018). Reports from the World Customs Organization. International Customs Officer Day. Available at: http://sfs.gov.ua/media-tsentr/novini/print-324445.html (accessed 10 January 2020).

State Customs Service (2019). Statutes of the State Customs Service of Ukraine. Available at: http://customs.gov.ua/polozhennia (accessed 10 January 2020).

United Nations Environment Programme (2008). Green customs: guide to multilateral environmental agreements. Available at: http:// www.unep.fr/ozonaction/information/mmcfiles/7466-r-Greencustoms Guide.pdf (accessed 10 January 2020).

Ukrainian Universal Exchange (2020). Illegal logging in Ukraine: prohibit impossible to permit. Available at: http://www.openforest.org.ua/130991) (accessed 10 January 2020).

State Forest Agency (2020). Volumes of illegal logging in Ukraine increased sevenfold. Available at: http://www.unian.ua/ecology/10903121-v-ukrajini-obsyagi-nezakonnih-rubok-zrosli-v-sim-razivderzhlisagentstvo.html (accessed 10 January 2020).

Compass Guide Ukranian (2016). Manual for the achievement of Goals of Sustainable Development in the sphere of business. Available at: http://sdgcompass.org/wp-content/uploads/2016/09/SDG Compass_Guide_Ukrainian.pdf (accessed 10 January 2020).

Herasymchuk, Z. V., Vakhovych, I. M., \& Kaminska, I. M. (2006). Financial policy of sustainable development of the region. Lutsk: Nastyrya.

Kravchenko, V. (2019). Green Customs. Will Zelenskyy become the first President who defeats smuggling. Available at: http://focus.ua/economics/435093-zeljonaia_tamozhnia (accessed 10 January 2020). 